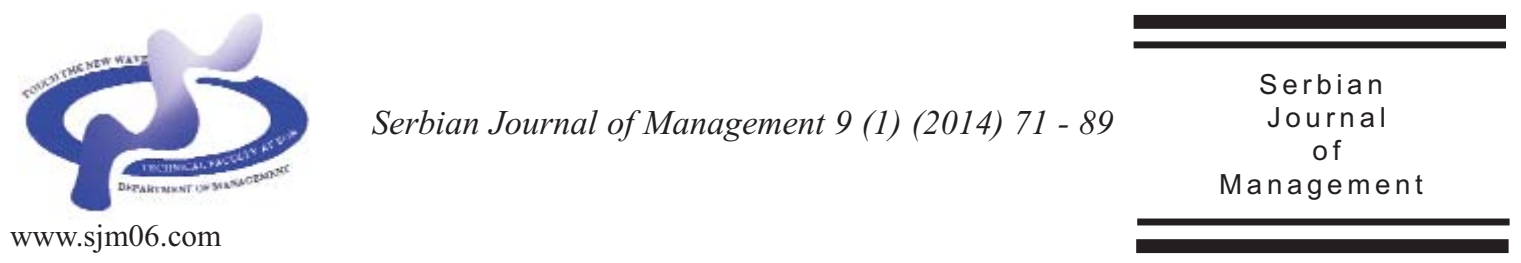

\title{
AN EMPIRICAL ANALYSIS OF CAUSE OF CONSUMER DISSATISFACTION AND THE REASONS WHY CONSUMERS ENDURING DISSATISFACTION
}

\author{
Satya Narayan Mahapatra* \\ Department of Management Studies, Deenbandhu Chhotu Ram University of \\ Science \& Technology, Murthal, India
}

(Received 12 December 2013; accepted 3 March 2014)

\begin{abstract}
The consumer dissatisfaction subject is still interesting and challenging for conducting academic research and therefore in this paper efforts are made to find out the possible cause of consumer dissatisfaction and the reasons why consumers are enduring the dissatisfaction. The study was conducted in Dehradun, the capital city of Uttarakhand (India), where 212 questionnaires were circulated among the respondents (male \& female) of different age, income, occupation and different academic background. The primary data collected from these respondents were analyzed to study the equations developed for empirical research. The results obtained from the factor analysis and correlation matrix explain that the firms consumer care, consumer expectations and firms commitment are the main causes for consumer dissatisfaction. However the firms commitment is the most important factor in causing dissatisfaction. Similarly this paper has brought out some facts about the reasons why consumers are enduring dissatisfaction. Many a time consumers are not reporting their dissatisfaction and not lodging dissatisfaction complain, instead of that they are enduring dissatisfaction. The product services, warranty and time factor are the reasons due to which consumers are enduring dissatisfaction. The implications of this paper will help in resolving the issues of consumer dissatisfaction for firm and strengthen the firms in understanding why consumer enduring dissatisfaction.
\end{abstract}

Keywords: Analysis of causes; Consumers; Dissatisfaction; Endurance; Reasoning

\footnotetext{
* Corresponding author: snm986@gmail.com
}

DOI: $10.5937 /$ sjm9-5181 


\section{INTRODUCTION}

Traditionally, both practitioners and academicians have focused on consumption evaluations in the form of satisfaction and dissatisfaction representing whether product consumption is viewed as providing the consumer with a favourable or unfavourable experience. Oliver (1987) pointed out although dissatisfaction is an essential prerequisite for complaint behaviour, not every dissatisfied consumer will complain. Fornell and Didow (1980) without knowing the customer's reason for being unhappy, the task of taking corrective actions to avoid or minimize future unhappiness becomes all the more challenging. In addition, dissatisfied customers who do not voice their complaints are more likely to take their business elsewhere. Krishnan and Valle (1979) the study of consumer behaviour is important from both marketing management and social welfare perspective and consumer complaints constitute an important feedback mechanism for marketing management to monitor consumer satisfaction with their products and services where as noncomplaint by dissatisfied consumers block off this feedback may decide not to buy the product again or warn family and friends to avoid the product, which can be costly to the marketer. Without knowledge of the sources of dissatisfaction, management will be unable to change its procedures. Westbrook (1977) consumer satisfaction and dissatisfaction are widely inclusive concepts. It not only do they subsume the full extent of an individual's product and service purchase, but they also include markedly different aspects of consumer behaviour-namely, product acquisition, consumption and disposition. In other words, for any given purchase, consumers may be satisfied or dissatisfied to varying degrees in connection with each of the separate activities of acquiring the product, using or consuming its benefits, and disposing of it.

The paradigm that has dominated consumer satisfaction/dissatisfaction research since its emergence as a legitimate field of inquiring in the early 1970's has been the expectancy disconfirmation paradigm. Oliver (1980) according to this paradigm, consumers are believed to form expectations about a product prior to purchasing the product. Tolman (1932) the notion of consumers forming expectations is derived from expectancy theory and is generally defined as a consumers' beliefs that a product has certain desired attributes. Pfaff (1972) the importance of assessing customer satisfaction and dissatisfaction (CS/D) has been documented extensively since 1970 , when the, United States Department of Agricultures Index of Consumer Satisfaction reported on CS/D information to policy makers. Greyser (1976) noted that there was inadequate conceptualization and measurement of CS/D and he proposed CS/D research must be grounded in the use of CS/D: (1) as social indicator-an index providing a longitudinal measure noting changes in CS/D overtime; (2) as central to, and a goal of, an economic system; (3) as a guide to policy, planning and evaluation, to give policy makers conceptual and measurement support for their decision making; (4) as a guide in specific regulatory matters; (5) to support public policy making decisions in consumer legislation; (6) as a central precept of the marketing strategy of a business; (7) in consumer activities allowing activities to focus attention on those aspects which show the lowest level of satisfaction, and (8) as a basis for developing theories of consumer behaviour. 
There are several social science researchers published research papers on consumer satisfaction/dissatisfaction and complaining behavior but the purpose of this paper is to find out the real causes of consumer dissatisfaction and why the consumers are enduring dissatisfaction while using the products. This paper examines the various reasons that forcing the consumers to endure dissatisfaction. Day and Ash (1978) examine this aspect earlier and did a comparison of satisfaction/dissatisfaction and complaining behaviour for durables, non-durables and services that in general there seemed to be more instance of dissatisfaction but a lower rate of complaining and redress seeking for consumer non-durables.

\section{CONSUMER DISSATISFACTION AND LITERATURE REVIEW}

$\begin{array}{rrr}\text { Random House } & \text { Dictionary defined } \\ \text { dissatisfaction as resulting from }\end{array}$
"contemplating what falls short of one's wishes or expectations" (Gilly, 1979). Theory that developed to explain the concept of consumer satisfaction/Dissatisfaction (CS/D) includes (1) economic theory (2) cognitive theory (3) affective theory and communications-effect theory. Sirgy (1980) economic theory attempted to explain CS/D in terms of "consumer surplus". It is assumed that consumer surplus of goods or value of a specific good would lead to satisfaction and consumer shortage would lead to its dissatisfaction. Cognitive theory, on the other hand, explains CS/D in terms of discrepancies between ideal and actual product performance. Affective theory explains $\mathrm{CS} / \mathrm{D}$ in terms of subjectively felt needs, aspirations, and experiences which may not be a reflection of the narrowing or widening discrepancies between ideal and actual product performance but simply due to personality change and/or other trend factors. The communication effect theory postulates that any observed changes to CS/D may be simply the result of a communication or message effect. Day (1983) has defined CS/D as an emotional response manifested in feelings and is conceptually distinct from cognitive responses, brand effect and behavioural responses. Oliver and DeSarbo (1988) explain satisfaction that it can be thought of as a feeling of "delight" and dissatisfaction a feeling of "disappointment". In general researchers agree that the concept of consumer satisfaction/dissatisfaction refers to an emotional response to an evaluation of a product, store or service consumption experience.

Westbrook (1977) consumer dissatisfaction indicates the degree of unfavourability of an individual's experiences associated with his or her behaviour. Summers and Granbois (1977) define that consumer dissatisfaction is a function of the comparative levels of consumers' expectations and their actual performance with goods and services is a potentially powerful source of explanation for several kinds of variability in actual dissatisfaction. The relationship between expectations and experience also seems relevant for another aspect of consumer dissatisfaction which received much research attention. Although the character of the process underlying this behavior is still not properly understood, a number of previous studies have documented wide differences in the incidence of such behaviour over product classes and consumer categories, and the intensity of the complaining response itself 
seems highly variable. Fornell and Didow (1980) consumer satisfaction/Dissatisfaction $(\mathrm{CS} / \mathrm{D})$ is one measure of economic system performance and consumer complaints are indicators of low or declining performance. Majority of dissatisfied consumers do not voice their complaints and several conceptual models of the consumer dissatisfaction/complaining process have been proposed (Beh \& Loo, 2013; Day and Landon, 1977; Landon, 1977; Fornell, 1976). Landon's model is an attempt to integrate previous research on complaint behaviour and it postulates that dissatisfaction, importance, benefit from complaining and personality are the basic determinants of complaining behaviour. Fornell's model of the consumer post-purchase evaluation specifies a functional relationship between perceived performance and prior expectations that is affected by both consumer and market variables. Taylor and Burns (1999) define consumer satisfaction/dissatisfaction is a function of the consumer's expectations about the product performance, the product's delivered performance, and some form of comparison between the pre-purchase expectations and the post-purchase performance. Under the basic expectancy-disconfirmation model, when perceived product performance exceeds the consumer's expectations (positive disconfirmation) leads to satisfaction, when perceived product performance falls below expectations (negative disconfirmation) leads to dissatisfaction. Andreasen and Best (1977) a more complex sequence of $\mathrm{CS} / \mathrm{D}$ change can also ensue when a consumer reacts to perceived dissatisfaction by complaining (either to the marketer or a third party), and then have a reversed CS/D reaction after the problem has been resolved. Dick,
Hausknecht and Wilkie (1995) consumer may not seek redress from the marketer or some third party agency but may content themselves with "warning" friends and acquaintances about the trouble they have experienced. Some consumer may not even go that far, but rather decide that they will personally avoid the brand (or product class, etc. depending on where they attribute the locus of the feelings). This can have especially troublesome effects if the dissatisfaction feeling has resulted from failure at the end of the product's useful life and the main focus of the research was on product use experience, CS/D, complaining, disposition and warranties. Anderson (1971) dissatisfaction results from contemplating what falls short of one's wishes or expectations and is usually only temporary. From this definition it can be hypothesize that consumer dissatisfaction is a result of market offerings which fall short of consumer expectations. Zeelenberg and Pieters (2004) analyzed the consumer dissatisfaction and its related behaviours by using a specific emotion approach i.e. valence-based approach and specific emotion approach. According to them customer dissatisfaction is not only a function of disappointment (i.e. the amount of negative disconfirmation), but also of regret (i.e. the performance of forgone alternatives). Dissapointment is felt when actual service delivery violates prior held expectations, whereas regret is typically felt following a bad choice of service provider (i.e. when it turns out that a forgone provider would have delivered a better service). Regret is likely to result in a focus on nonattained goals and promote goal persistence; disappointment may result in goal abandonment. Another variable "inertia" was analyze by them in their study of failed 
service and they defined inertia-doing nothing in response to a failed service encounter and this behavioural response of the consumer was added since often customers just do not react at all when a bad thing happens, and this might be related to be a relevant behavioural response for both regret and disappointment. Many times in the case of failed service encounters, customers do not react at all, or they experience a lack of behavioural action in response to the failure. Hence inertia is defined as the experienced absence of goaldirected behavior.

Singh (1990) reviewed the consumer dissatisfaction response style and tried to indentify the gaps and provided guidelines for a programmatic and systematic research into consumer dissatisfaction response style. On the basis of reviewing the past research on consumer dissatisfaction there is empirical evidence that some consumers do not rely on private (or public) action only to deal with their dissatisfaction whereas another study proposed an identical typology of response styles and these styles are (I) Upset-no action and (II) Upset-action. The first group represents dissatisfied consumers who do not take any action and consumers who took some action(s) fall in the second group. Researchers have used different labels for these styles such as complainers and non-complainers and activists and nonactivists whereas Warland (1977) proposed five group typology i.e. concerned complainers/non-complainers, unconcerned complainers/non-complainers and uninformed non-complainers. In his study on the extent of consumer dissatisfaction it was observed from the same data that among the dissatisfied consumers about 25 percent had taken no action, 32 percent consumers had complained directly to the retailer/manufacturer and the remaining 43 percent were distributed over the other ten types of response(i.e. stopped shopping, complained to friends, etc.).

The critical step in understanding and management of consumer dissatisfaction is mapping how consumers respond to perceived dissatisfaction. This is a relatively complex issue since consumers can choose from innumerable combinations of multiple dissatisfaction responses (i.g. complaining to retailer and negative word of mouth communication to friends and relatives). Lundstrom, White and McAuley (2004) did a cross cultural comparison of consumer dissatisfaction between US and UK consumers and analyze their discontent. They constructed the discontent scale composed of 41 items to measure the positive and negative affect towards business practices and business attitudes. In close examination of the individual structures it reveal similarities and dissimilarities exist across cultural and geographical boundaries. The research indicated that the dimensionality of consumer discontent has remained fairly constant over time and that the short form consumer Discontent Scale still exhibits reliability and consistency. LaBarbera and Mazursky (1983) measured satisfaction/dissatisfaction to estimate post purchase evaluation. In their longitudinal assessment of consumer satisfaction/dissatisfaction and path analysis model the repeat purchase tested as a categorical variable (repeat purchase versus brand switchers), satisfaction/dissatisfaction estimates post purchase evaluations, and intention is believed to act as the adaptation variable. In their research they have found a high satisfaction level will have a point impact on the intention level for repeat purchasers, whereas dissatisfaction could 
have a negative influence on the intention level for brand switchers. Richins (1983) investigated the negative word-of-mouth by dissatisfied consumers. The managers are using complaints rates as dissatisfaction indicators and assuming that if complaint rates are low, overall dissatisfaction is low. He analyzes the dissatisfaction and negative word-of-mouth by taking data from the different consumers who purchased products from different retailers. His observation was if a consumer is dissatisfied enough to take some action in response to a dissatisfaction, the less positive the perception of retailer responsiveness, the greater the likelihood the action will involve word-of-mouth but not complaint behavior. The study also shown that the nature of the dissatisfaction problem, consumers' attributions of blame for dissatisfaction and perceptions of the complaint situation are related to responses to dissatisfaction. Cho et. al. (2003) analyzes the customer dissatisfaction with report to product category for cyber space. Their study attempted to analyze how customers' dissatisfaction and propensity to complain differ by different product categories on web. They used three variables perceived price, information search effort and ego involvement and revealed that the impact of perceived price, information search effort and ego involvement on the degree of dissatisfaction are significantly affected by product category. The findings implied that online customers are more dissatisfied with sensory products than non-sensory products as they spent more effort on searching the information on sensory products than nonsensory product; they involve more on purchasing sensory products than nonsensory products; and they cost more on sensory products than non-sensory products. Singh and Widing(1991) proposed theoretical model for understanding the satisfaction/Dissatisfaction outcomes of complaint response provided some light about customer complaint responses and given the idea of difference between initial dissatisfaction and final satisfaction/dissatisfaction. The model of Consumer Complaint Response (CCR) evaluation process attempted to understand the relationship between the CCR evaluation process and future attitudes link by applying well developed theories. Most of the previous research treated the dissatisfaction from consumption experiences passively i.e. dissatisfaction is expected to influence future attitudes and intentions negatively whereas their model attempted to describe a process oriented framework that explains how initial dissatisfaction might be converted into final satisfaction. The testable hypothesis proposed by the researchers i.e. first hypothesis; the future attitude towards the focal product/seller(FA) are a function of final feelings of satisfaction are dissatisfaction, the second proposition proposes that final feelings of satisfaction/dissatisfaction are a function of perceived level of sellers response, the normative level of response and the extent of disconfirmation. The third hypothesis is that disconfirmation is itself a function of the difference between the perceived and normative level of sellers response, the fourth proposition state that perceived level of seller's response is formed by the individual's expectations about the seller's responsiveness, attitude towards the act of complaining and the seller's actual complain resolution mechanism. The fifth hypothesis proposed that the normative level of comparison is a direct function of an individual's norms about seller's responsiveness that have been derived from 
outcome experiences across dissatisfaction episode. These testable hypothesis proposed by the researchers are useful hypothesis for studying the consumer satisfaction and dissatisfaction. Wee and Cheong (1991) empirical study on determinant of consumer satisfaction/Dissatisfaction towards dispute settlement has provided information about consumers' satisfaction and dissatisfaction towards dispute settlement. The researchers argue that previous literature on consumers (CS/D) has done little study about this aspect therefore they had selected different line to study the consumers' satisfaction/dissatisfaction. Their empirical study uncovered the determinant of $\mathrm{CS} / \mathrm{D}$ towards dispute settlement for consumers of various constructs i.e. individual differences household differences, the amount of purchase compensation and time taken. Singh and Pandya (1991) made effort in the direction of finding out the relationship between consumer dissatisfaction (CD) and Consumer Complaint Behaviour (CCB) in their empirical research work in ninety. Their study show that in general, higher the dissatisfaction, the strong the relationship between attitudes and behaviours and proposed two possibilities of CD's role in $\mathrm{CCB}$ i.e. $\mathrm{CD}$ has a non-linear relationship with $\mathrm{CCB}$ and $\mathrm{CD}$ moderates the relationship between attitude towards complaining and CCB. Bell and Zemke (1987) categorize the levels of dissatisfaction and suggested customers' feelings about service failures/breakdown that fall into two distinct levels of dissatisfaction i.e. 'annoyance' and victimization. Annoyed customer feel inconvenience when they experience service failure is less than expected and a victimized customer is left with a major feeling of ire, frustration or pain, dependant and angry. Prakash (1991) suggested the researchers need to study the multi dimensionality of dissatisfaction rather than treating it as the bipolar end of dissatisfaction and as per his view this is a vast open area for research. Johnston (1998) study on services to find the relationship between intensity of dissatisfaction on complaining behavior has provided new finding on consumer dissatisfaction. According to him consumers' complaining behavior is influenced by the different intensity of dissatisfaction. Some consumer, share dissatisfaction incidence with their friends and some consumer even go further and actively campaign against the company by taking serious legal action and petitioning outside the organization involved. The study confirms that the intensity of dissatisfaction is directly linked to the numbers of friends and acquaintances told about the incident. Davidow and Uttal (1989) express dissatisfaction by quoting dissatisfied customers are like a time bomb as they rapidly undo all the good created by large marketing budgets by spreading not only the bad news but also mismarket the organization and services very seriously. Bloemer, et.al. (2002) study on latently dissatisfied consumers in banking industry used datamining technique based on rule of characteristics argued that a satisfied consumer may defect because the customers who are satisfied overall about the services have possessed the characteristics of dissatisfied customer. The latently dissatisfied customer defined as customers who when asked, report overall satisfaction, but who possess other characteristics that are strongly associated with dissatisfaction. Day (1984) study on consumer dissatisfaction in his work on alternatives responses to dissatisfaction explained that complaining behavior is logically subsequent to dissatisfaction and is a distinct set of 
activities which are influenced by a variety of personal and situational factors and it appear to be unrelated to the intensity of dissatisfaction. Dissatisfaction is viewed as a state which motivates the consumer to consider engaging in one or more complaining activities but otherwise is not a factor in determining the outcome of the complaining/non complaining decision process. It is further interpreted that the emotional state generated by dissatisfaction motivates the consumer to complain but the subsequent decision making process depends not so much on how strong the emotions triggered by dissatisfaction but on the consumer's answers to certain questions. Mills (1981) exploratory study about dissatisfaction and consumer deviance on retail store and some new findings on the relationship between the level of consumer satisfaction with a store and the incidence of deviant consumer behavior committed against that store. FitzPatrick, Friend and Costley (2004) study on dissatisfaction and distrust by analyzing the nasty stories of the customer experienced in shopping is an eye opening study in consumer dissatisfaction. Their study in consumer dissatisfaction was different from the earlier study done in seventies and eighties. Their research finding emphasize that there is a need to understand much more about the complexity and intensity of emotions that occur in consumer experiences and how they contribute to dissatisfaction. Consumers feel distrust as an intense emotional, physiological, psychological, sociological and moral phenomenon. Distrust can lead to intense emotion, which contribute largely to dissatisfaction and their study on dissatisfaction was different from the earlier study in seventies and eighties. Day and Ash (1979) study on consumer response to dissatisfaction with consumer durable, nondurable and services/intangible products reported consumers are dissatisfied due to inferior quality, performance below expectation for durable products and in case of services it was the problem of warranties. Many times most of the consumers are dissatisfied but the consumer complain about their dissatisfaction when they see there is a real favourable outcome of the consumer complaint and the reason for dissatisfaction also varied in different types of durable product and the concern about product quality or performance tended to overshadow other possible causes of dissatisfaction. Oliver (1987) study in understanding the satisfaction-complaining in three different areas i.e. magnitude of the association between satisfaction and complaining, partial replication of earlier study by the past researchers and complaining or non-complaining relation to subsequent satisfaction that satisfaction/dissatisfaction is not a sufficient condition for complain to occur and dissatisfaction has many manifestations other than complaining.

\section{OBJECTIVES OF STUDIES}

Since seventies lot of academic research conducted on consumer satisfaction and dissatisfaction. Several researchers tried to explore the concept of consumer dissatisfaction by analyzing different objectives and hypothesis. Consumer dissatisfaction and consumer complaining behaviour topic studied for both tangible and intangible goods and in seventies most of the researchers tried to define consumer dissatisfaction in their study and purpose of study was to know the resultant occurrence of dissatisfaction and why there is consumer 
dissatisfaction. From the literature review of past study it has been observed that earlier study cited the outcome of consumer dissatisfaction which resulted in negative word of mouth publicity about the brand, consumer complaint, brand switching by the consumers and non-purchase of the goods if consumer complaints are not redressed by the firms or dealers. Besides consumer dissatisfaction works also done on consumer complaining behaviour, inertia in consumer complaining, regret and disappointment, ire, frustration, pain, anger and intensity of consumer dissatisfaction and complaining behaviour. Besides several study on consumer dissatisfaction and complaining behaviour the topic is still very much relevant in marketing discipline today and encouraging the marketing professors to explore further. Fornell and Wernerfelt (1987) argued that the study of consumer dissatisfaction is fundamental to a sound defensive marketing strategy therefore the objectives of studies for research in this paper is to identify the factors that causing consumer dissatisfaction and the reasons why consumers are enduring dissatisfaction.

\section{METHODOLOGY AND DATA COLLECTION}

The focus of this paper is to study the consumer dissatisfaction and to find out the reasons why consumer endures dissatisfaction. In order to decide the use of research design an exhaustive literature review was done on consumer satisfaction and dissatisfaction. On the basis of review of previous study it is decided to use descriptive research design and will be appropriate in studying the objectives. To study why consumer enduring dissatisfaction and the reason of enduring dissatisfaction number of possible reasons are identified for consumer survey. For this research items commonly used by the consumers were selected and the list include both tangible and intangible items such as Cable TV, Television, Washing Machine, Refrigerator, Air-conditioner, Land-Line Telephone Service, Cell Phone Service, DVD Player, DTH, Banking services, Digital Camera, Insurance, Laptop and utility services such as Postal services and, Electricity. The purposes of selecting these items are because these items are widely used by consumers. For primary data collection a structured questionnaire was designed and circulated among the consumers in "Dehradun", capital city of Uttarakhand a state of India. Initially the questionnaires were circulated to few respondents to know the shortcomings and mistakes so that the questionnaire can be improved further. After correction and improvement the final draft of the questionnaire was prepared for circulation and the same questionnaire was given to 212 respondents. To know the cause of dissatisfaction and reasons of endurance the respondents were asked to rate the factors in seven point interval scale. The respondents were asked to rate the causes of dissatisfaction from "High cause" to "Low cause" and weight 7 was assign to "High cause" and weight 1 was assign to "Low cause". Similarly to know the reasons why consumer enduring dissatisfaction the respondents were asked to rate the reason of endurance from "Highest reason" to "Lowest reason" of enduring dissatisfaction and weight 7 was assign to "Highest reason" and weight 1 was assign to "Lowest reason". The questionnaires were circulated to both male and female respondents belong to different income group, age, occupation and 
education. Out of total 212 questionnaire circulated for data collection, 12 questionnaires were found unfit for data analysis therefore 200 questionnaires are considered for analysis. Table-1 gives the detail description of respondents' profile who participated in the survey. Of the total 200 respondents $72 \%$ were male and $28 \%$ were female. Their age distribution was $27 \%$ belong to $25-35$ years, $36 \%$ belong to $35-45$ years age, $26 \%$ belong to $45-55$ years and $11 \%$ respondents were belonging to above 55 years age. The academic qualification; $26 \%$ respondents were simple graduates, $41 \%$ were simple post graduates and 33\% were having professional/technical degree. The occupation and income profile of the respondents were like this; $23 \%$ respondents were government employees, $42 \%$ were privately employed and $35 \%$ respondents were having their own business. The monthly income of the respondents are like this; $24 \%$ respondents had monthly income of less than INR $10,000,41 \%$ had monthly income of INR 10,000-20,000, 21\% had monthly income of INR20,000-30,000, 5\% had monthly income of INR 30,000-40,000, $6 \%$ had monthly income of INR 40,00050,000 and $3 \%$ respondents had monthly income more than INR 51,000.

For analysis of factors and reasons the following equations are used and mathematically we have expressed in the following manner.

The factors that causing consumer dissatisfaction are:

$$
\begin{aligned}
& \mathrm{Y}_{\mathrm{CD}}=f\left(\mathrm{X}_{\mathrm{CE}}, \mathrm{X}_{\mathrm{PT}}, \mathrm{X}_{\mathrm{PC}}, \mathrm{X}_{\mathrm{PS}}, \mathrm{X}_{\mathrm{CC}}, \mathrm{X}_{\mathrm{IP}}, \mathrm{X}_{\mathrm{FC}}\right) \\
& \mathrm{Y}_{\mathrm{CD}}=\text { Consumer Dissatisfaction } \\
& \mathrm{X}_{\mathrm{CE}}=\text { Consumer expectations } \\
& \mathrm{X}_{\mathrm{PT}}=\text { Product trouble } \\
& \mathrm{X}_{\mathrm{PC}}=\text { Product compatibility } \\
& \mathrm{X}_{\mathrm{PS}}=\text { Poor service } \\
& \mathrm{X}_{\mathrm{CC}}=\text { Consumer care } \\
& \mathrm{X}_{\mathrm{IP}}=\text { Inconvenience in handling the }
\end{aligned}
$$

\begin{tabular}{|c|c|c|c|c|}
\hline GENDER & AGE & EDUCATION & OCCUPATION & INCOME (In INR) \\
\hline Male: $72 \%$ & $25-35: 27 \%$ & Graduate: $\mathbf{2 6 \%}$ & \multicolumn{2}{|c|}{ Govt. Employee:23\% < 10,000:24\% } \\
\hline \multirow[t]{6}{*}{ Female: $28 \%$} & $35-45: 36 \%$ & Post Graduate:41\% & Pvt.Employee:42\% & $10,000-$ \\
\hline & $45-55: 26 \%$ & Professional/ & Own Business:35\% & $20,000: 41 \%$ \\
\hline & $>55: 11 \%$ & \multirow{4}{*}{\multicolumn{2}{|c|}{ Technical Degree: $33 \%$}} & $\begin{array}{l}20,000- \\
30,000: 21 \%\end{array}$ \\
\hline & & & & $\begin{array}{l}\text { 30,000- } \\
\text { 40,000: } 5 \%\end{array}$ \\
\hline & & & & $\begin{array}{l}40,000- \\
50,000: 6 \%\end{array}$ \\
\hline & & & & $>50,000: 3 \%$ \\
\hline
\end{tabular}
product

$\mathrm{X}_{\mathrm{FC}}=$ Firm commitment made to consumer at the time of purchase

Table 1. Description of Respondents Profile 
The reasons why the consumers are seven sets of possible causes were identified enduring dissatisfaction are:

$\mathrm{Y}_{\mathrm{RED}}=f\left(\mathrm{X}_{\mathrm{FC}}, \mathrm{X}_{\mathrm{TF}}, \mathrm{X}_{\mathrm{HS}}, \mathrm{X}_{\mathrm{CCL}}, \mathrm{X}_{\mathrm{AS}}, \mathrm{X}_{\mathrm{FW}}\right)$ and the exact numbers of factors that are causing consumer dissatisfaction are extracted through factor analysis. For each respondent who purchased or subscribed the $\mathrm{Y}_{\mathrm{RED}}=$ Reason of enduring dissatisfaction products and services were asked to know his/her cause of dissatisfaction. These data was factor analyzed using principal component analysis with varimax rotation in order to see which factor set could be formed and these results are shown in Table $2 \&$ Table 3. Three factors emerge from the factor analysis of seven factors and factor loadings of .4 or greater are enclosed in brackets. Factor 1 labeled Firms consumer care include; poor service and consumer care. The second factor is labeled Consumer expectations include; consumer expectations, product trouble and product

\section{DATA ANALYSIS AND DISCUSSION} compatibility. The third factor labeled Firms commitment includes; inconvenience in

In order to find out the actual factors that are causing dissatisfaction to consumers' handling the product and firms' commitment made to consumer at the time of purchase.

Table 2. Varimax Rotated Factor Matrix

\begin{tabular}{|c|c|c|c|}
\hline Variables & Factor 1 & Factor 2 & Factor 3 \\
\hline 1. Consumer expectations & .105 & {$[.736]$} & .098 \\
\hline 2. Product trouble & -.135 & {$[.681]$} & -.320 \\
\hline 3. Product compatibility & .260 & {$[.490]$} & .377 \\
\hline 4. Poor service & {$[.806]$} & .193 & .091 \\
\hline 5. Consumer care & {$[.767]$} & -.078 & .171 \\
\hline $\begin{array}{l}\text { 6. Inconvenience in handling } \\
\text { the product }\end{array}$ & -.127 & .148 & [.769] \\
\hline $\begin{array}{l}\text { 7. Firms' commitment made to } \\
\text { consumer at time of purchase }\end{array}$ & .185 & -.168 & {$[.634]$} \\
\hline Explained Variance per Factor & $19.78 \%$ & $19.12 \%$ & $18.35 \%$ \\
\hline Cumulative & $19.78 \%$ & $38.91 \%$ & $57.26 \%$ \\
\hline
\end{tabular}

No. of cases 200

[ ] indicates the highest loading in each row 
Table 3. Emerging Factors Causing Consumer Dissatisfaction

Factor 1 Firms consumer care

- Poor service

- Consumers' care

Factor 2 Consumer expectations

- Consumers' expectations

- Product trouble

- Product compatibility

Factor 3 Firms commitment

- Inconvenience in handling the product

- Firms' commitment made to consumer at the time of purchase

.806

.767

.736

.681

.490

.769

.634
$\mathrm{Y}_{\mathrm{CD}}=$ Consumers dissatisfaction

$\mathrm{X}_{\mathrm{FCC}}=$ Firms consumer care

$\mathrm{X}_{\mathrm{CEX}}=$ Consumer expectations

$\mathrm{X}_{\mathrm{FCM}}=$ Firms commitment
To know the number of possible reasons that why consumers endure dissatisfaction are measured by performing the factor analysis using Principal Component analysis with varimax rotation so that set of reasons could be formed on the basis of similarity of dissatisfaction score and the results are shown in Table $4 \&$ Table 5 . Three factors emerge from factor analysis and factor loading greater than .7 consider for grouping together.

Therefore Factor 1 labeled Product services include; high service cost and non availability of authorize service centre. Factor 2 labeled Warranty include; firms' inability in solving consumers complaint and firms' poor commitment to warranty. Factor 3 labeled Time factor include; firm ignoring consumers' complaint and time factor.

$\mathrm{Y}_{\mathrm{RED}}=f\left(\mathrm{X}_{\mathrm{PDS}}, \mathrm{X}_{\mathrm{WRR}}, \mathrm{X}_{\mathrm{TMF}}\right)$

Table 4. Varimax Rotated Factor Matrix

\begin{tabular}{|c|c|c|c|}
\hline Variables & Factor 1 & Factor 2 & Factor 3 \\
\hline 1.Firm ignoring consumer's complaint & -.022 & -.084 & {$[.763]$} \\
\hline 2. Time factor & -.080 & .126 & {$[.748]$} \\
\hline 3. High service cost & {$[.815]$} & .062 & -.055 \\
\hline $\begin{array}{l}\text { 4. Firms' inability in solving the } \\
\text { consumers' complaints }\end{array}$ & .028 & {$[.816]$} & .040 \\
\hline \multicolumn{2}{|c|}{ 5. Non availability of authorize service centre [.796] } & .085 & .118 \\
\hline $\begin{array}{l}\text { 6. Firms' poor commitment } \\
\text { to warranty }\end{array}$ & .115 & {$[.768]$} & -.002 \\
\hline Explained Variance per Factor & $21.98 \%$ & $21.47 \%$ & $19.34 \%$ \\
\hline Cumulative & $21.98 \%$ & $43.45 \%$ & $62.80 \%$ \\
\hline
\end{tabular}

No. of cases 200

[ ] indicates the highest loading in each row 
$\mathrm{Y}_{\mathrm{RED}}=$ Reason of enduring dissatisfaction

$\mathrm{X}_{\mathrm{PDS}}=$ Product services

$\mathrm{X}_{\mathrm{WRR}}=$ Warranty

$\mathrm{X}_{\mathrm{TMF}}=$ Time factor

Table 5. Emerging Factors for Consumer Enduring Dissatisfaction

Factor 1 Product services

- High service cost

- Non availability of authorize service centre .815

.796

Factor 2 Warranty

- Firms' inability in solving consumers complaint

- Firms' poor commitment to warranty

.768

Factor 3 Time factor

- Firm ignoring consumers' complaint $\quad .763$

- Time factor

This paper attempted to find out the actual factors that are causing consumer dissatisfaction and the reasons why consumers are enduring dissatisfaction. In the objectives of study the factors causing consumer dissatisfaction and reasons of enduring dissatisfaction are defined in equation $1 \& 2$. To extract the actual number of factors and reasons factor analysis method is used with varimax rotation. From the factor analysis three factors for cause of

consumer dissatisfaction and three reasons for enduring dissatisfaction are obtained which are defined in equation $3 \& 4$. In equation 1 we consider seven factors initially but after factor analysis we extracted three factors i.e. firms consumer care, consumers expectations and firms commitment which are causing consumer dissatisfaction and it is defined in equation 3. Similarly in equation 2 we consider six reasons initially but we extracted three reasons i.e. product services, warranty and time factor due to which consumers are enduring dissatisfaction and it is defined in equation 4.

The predictability of firms consumer care, consumer expectations and firms' commitment on consumers' dissatisfaction is measured by using the multiple regression analysis. The multiple regression results for factors causing consumer dissatisfaction (see Table 6) shows that $\mathrm{R} 2=.015, \mathrm{~F}=.969$ and Durbin-Watson $=.069$. Similarly the predictability of product services, warranty and time factor on reason of enduring dissatisfaction is also measured with the help of using multiple regression analysis. The multiple regression results for reasons consumers enduring dissatisfaction (see Table 7) shows that $\mathrm{R} 2=.043, \mathrm{~F}=2.912$ and Durbin-Watson $=.122$. All the factors that extracted from factor analysis are further

Table 6. Multiple Regression Results for Factors Causing Consumer Dissatisfaction

\begin{tabular}{lllc}
\hline Independent Variables & $\boldsymbol{\beta}$ Coefficients & $\boldsymbol{t}$-Value & Significance \\
\hline $\mathrm{X}_{\mathrm{FCC}}$ & -.013 & -.180 & .857 \\
$\mathrm{X}_{\mathrm{CEX}}$ & -.022 & -.312 & .755 \\
$\mathrm{X}_{\mathrm{FCM}}$ & -.116 & -1.636 & .104 \\
\hline
\end{tabular}

Sample R2 $=.015$

Adjusted R2 $=.000$

Overall Degree of Freedom $=199$

$\mathrm{F}=.969$

Durbin-Watson $=.069$

Number of Cases $=200$ 
Table 7. Multiple Regression Results for Reasons Consumers Enduring Dissatisfaction

\begin{tabular}{llll}
\hline Independent Variables & $\boldsymbol{\beta}$ Coefficients & $\boldsymbol{t}$-Value & Significance \\
\hline $\mathrm{X}_{\mathrm{PDS}}$ & -.031 & -.436 & .664 \\
$\mathrm{X}_{\mathrm{WRR}}$ & -.152 & -2.164 & .032 \\
$\mathrm{X}_{\mathrm{TMF}}$ & -.136 & -1.944 & .053 \\
\hline
\end{tabular}

Sample R2 $=.043$

Adjusted R2 $=.028$

Overall Degree of Freedom $=199$

$\mathrm{F}=2.912$

Durbin-Watson $=.122$

Number of Cases $=200$

Table 8. Correlations Matrix

\begin{tabular}{|c|c|c|c|c|c|c|c|}
\hline & & $\mathrm{X}_{\mathrm{FCC}}$ & $\mathrm{X}_{\mathrm{CEX}}$ & $\mathrm{X}_{\mathrm{FCM}}$ & $\mathrm{X}_{\mathrm{PDS}}$ & $\mathrm{X}_{\text {WRR }}$ & $\mathrm{X}_{\mathrm{TMF}}$ \\
\hline \multirow{3}{*}{$\mathrm{X}_{\mathrm{FCC}}$} & Pearson Correlation & 1 & .136 & .000 & .102 & .104 & .071 \\
\hline & Sig. (2-tailed) & & .055 & .997 & .150 & .142 & .321 \\
\hline & $\mathrm{N}$ & 200 & 200 & 200 & 200 & 200 & 200 \\
\hline \multirow{3}{*}{$\mathrm{X}_{\mathrm{CEX}}$} & Pearson Correlation & .136 & 1 & .068 & .033 & .009 & .126 \\
\hline & Sig. (2-tailed) & .055 & & .338 & .645 & .897 & .076 \\
\hline & $\mathrm{N}$ & 200 & 200 & 200 & 200 & 200 & 200 \\
\hline \multirow{3}{*}{$\mathrm{X}_{\mathrm{FCM}}$} & Pearson Correlation & .000 & .068 & 1 & $.157^{*}$ & $.196^{* *}$ & .070 \\
\hline & Sig. (2-tailed) & .997 & .338 & & .026 & .005 & .322 \\
\hline & $\mathrm{N}$ & 200 & 200 & 200 & 200 & 200 & 200 \\
\hline \multirow{3}{*}{$\mathrm{X}_{\mathrm{PDS}}$} & Pearson Correlation & .102 & .033 & $.157^{*}$ & 1 & .102 & .021 \\
\hline & Sig. (2-tailed) & .150 & .645 & .026 & & .151 & .773 \\
\hline & $\mathrm{N}$ & 200 & 200 & 200 & 200 & 200 & 200 \\
\hline \multirow{3}{*}{$X_{\text {WRR }}$} & Pearson Correlation & .104 & .009 & $.196^{* *}$ & .102 & 1 & -.024 \\
\hline & Sig. (2-tailed) & .142 & .897 & .005 & .151 & & .738 \\
\hline & $\mathrm{N}$ & 200 & 200 & 200 & 200 & 200 & 200 \\
\hline \multirow{3}{*}{$\mathrm{X}_{\mathrm{TMF}}$} & Pearson Correlation & .071 & .126 & .070 & .021 & -.024 & 1 \\
\hline & Sig. (2-tailed) & .321 & .076 & .322 & .773 & .738 & \\
\hline & $\mathrm{N}$ & 200 & 200 & 200 & 200 & 200 & 200 \\
\hline
\end{tabular}

*. Correlation is significant at the 0.05 level (2-tailed).

**. Correlation is significant at the 0.01 level (2-tailed).

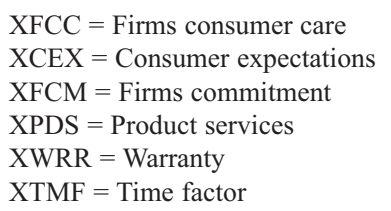

analyzed by using Pearson correlation correlation matrix is shown in Table 8. From analysis in order to know the significance the correlation matrix it has been observed level among the different variables and the that firms commitment and product services 
are significant (P .026) and similarly the firm commitment and warranty are significant $(\mathrm{P}$ $.005)$. From the correlation output and the significance level it can be further interpreted that firms commitment is a major factor out of seven which is causing consumer dissatisfaction and it can be defined in the following equation.

$$
\mathrm{Y}_{\mathrm{CD}}=f\left(\mathrm{X}_{\mathrm{FCM}}\right)
$$

Similarly the product services or services and the warranty are the two major reasons out of six reasons due to which the consumers are enduring dissatisfaction and this is defined by the following equation.

$\mathrm{Y}_{\mathrm{RED}}=f\left(\mathrm{X}_{\mathrm{PDS}}, \mathrm{X}_{\mathrm{WRR}}\right)$

Hence firms need to give importance to product services and the warranty aspects. It seems the firms are not fulfilling their commitments regarding providing good services and not obliging the warranty therefore the consumers are enduring dissatisfaction instead of reporting the firm about dissatisfaction.

\section{CONCLUSION}

It is clear that firms' commitments to consumer care and consumer expectations are the real causes for consumer dissatisfaction. Firm needs to address consumer dissatisfaction properly and timely in an appropriate manner. If firm fails to redress the consumers' dissatisfaction it might affect the customer loyalty and may create negative word of mouth publicity as reported earlier in previous study by Richin (1983). The reasons why consumers are not reporting their dissatisfaction is because consumers are enduring dissatisfaction due to cost of services and warranty. If there is dissatisfaction and consumers are not complaining then it is not a good sign for firm. It seems consumer knowingly not complaining and the marketing manager of the firm should analyze these reasons and try to encourage the consumers in expressing their grievances candidly otherwise consumer may share their experience with friends and relatives. The firm should revamp their grievance redressal system so that more and more consumer will come forward in future to report about their dissatisfaction. High service charges and authorize service centre is another concern area the firm should think. Firm should show more commitments towards warranty, pay attention to consumer complaints and respect consumers' time.

\section{MANAGERIAL IMPLICATIONS}

The result of this study has several implications for marketing managers and practitioners in context of consumer satisfaction and dissatisfaction. The empirical study on consumer dissatisfaction provided more insight to the firm and marketing practitioners in focusing on core issues of dissatisfaction. The outcome of this paper has two major implications. First implications the paper has provided the findings about major cause of consumer dissatisfaction. Earlier study may have pointed out some of these cause but these causes are still important factors in causing consumer dissatisfaction. Product compatibility, inconvenience and services, firms' commitment and quality, firms' attention to consumer care and consumer 
expectations are major cause for consumer dissatisfaction. It clearly indicates that the firms are not able to alleviate the cause of consumer dissatisfaction. This paper has provided information about the root cause of consumer dissatisfaction and why firm should take necessary action. The second important implications of this research is that this paper able to find out the reasons why consumer enduring dissatisfaction instead of lodging complain to firm and these reasons were not analyzed in earlier study. If the consumer is not lodging complain against the firms products or services it should not assume that consumer is satisfied. Initially it may appear that everything is alright from firms' perspective but from consumer's side new problem may originate because of enduring dissatisfaction. Consumer enduring of dissatisfaction may impact the firms marketing strategy on consumer behavior significantly. The result further emphasizes to analyze critically the consumer dissatisfaction. The output of this paper opens a new chapter for discussion on consumer satisfaction/dissatisfaction in academic and in business.

\title{
ЕМПИРИЈСКА АНАЛИЗА РАЗЛОГА НЕЗАДОВОЉСТВА КУПАЦА И РАЗЛОЗИ ЗБОГ КОЈИХ КУПЦИ ПОКАЗУЈУ НЕЗАДОВОљСТВО
}

\author{
Satya Narayan Mahapatra
}

\section{Извод}

Незадовољство купаца је још предмет интереса и изазов за спровођење академског истраживања. Због тога, у овом раду су учињени напори да се пронађе могући разлог незадовољства купаца и разлог због којег купци показују незадовољство. Проучавање је спроведено у Дехрадуну, главном граду Утараканда (Индија) где су попуњена 212 упитника од стране испитиника (мушкараца и жена) различитих година, прихода, занимања и различитих образовних структура. Прелиминарни подаци сакупљени од испитаника анализирани су да би се дефинисале једначине емпиријског истраживања.Добијени резултати факторске анализе и корелационе матрице, показали су да су брига компаније о купцима, очекивања купаца и посвећеност бренду главни узроци за потенцијално незадовољство купаца. Такође, рад је показао одређене чињенице о разлозима зашто купци показују али и подносе незадовољство. Много пута купци не пријављују своје незадовољство и не покрећу акције незадовољства, уместо тога они подносе незадовољство. Услуге које прате производе, гаранција и временски фактор су разлози због којих купци издржавају незадовољство. Закључци овог рада ће помоћи у решавању аспеката незадовољства купаца према компанијама и ојачаће саме компаније у разумевању због чега купци подносе незадовољство.

Кључне речи: Анализа разлога, купци, незадовољство, подношење, резоновање. 


\section{References}

Anderson, R.E. (1971). Consumer Dissatisfaction: The Effect of Disconfirmed Expectancy on Perceived Product Performance. University of Florida. Ph.D. Dissertation.

Andreasen, A.R., \& Best, A. (1977). Consumer Complain-Does Business Respond. Harvard Business Review, 55, 94104.

Beh, L-S., \& Loo, L-H. (2013). Human resource management best practices and firm performance: a universalistic perspective approach, 8(2), 155-167.

Bell, C.R., \& Zemke, R.E. (1987). Service Breakdown: the Road to Recovery. Management Review (October), 32-35.

Bloemer, J., Brijs, T., Swinnen, G., \& Vanhoof, K. (2002). Identifying latently dissatisfied customers and measures for dissatisfaction management. International Journal of Bank Marketing, 20(1), 27-37.

Cho, Y., Im, I., Fjermestad, J., \& Hiltz, S.R. (2003). The impact of product category on customer dissatisfaction in cyberspace. Business Process Management Journal, 9(5), 635-651.

Davidow, W.H., \& Uttal, B. (1989). Total Customer Service. New York: Harper Perennial.

Day, R.L. (1984). Modeling Choices Among Alternative Responses to Dissatisfaction. In T.C. Kinear (Ed.), Advances in Consumer Research, 11th ed. (pp. 496-499). Provo, UT: Association for Consumer Research.

Day, R.L. (1983). The Next Step: Commonly Accepted Constructs for Satisfaction Research. In R.L. Day \& K.H. Hunt (Eds.), International Fare in Consumer Satisfaction and Complaining Behavior. (pp. 113-117). Bloomington, IN: Indiana
University.

Day, R.L., \& Ash, S.B. (1979). Consumer Response to Dissatisfaction with Durable Products. In W.L. Wilkie (Ed.),Advances in Consumer Research, 6th. (pp. 438-444). Ann Abor: Association for Consumer Research.

Day, R.L., \& Ash, S.B. (1978). Comparison of Patterns of Satisfaction/Dissatisfaction and Complaining Behavior for Durables, NonDurables and Services, Proceeding of the Consumer Satisfaction/Dissatisfaction \& Complaining Behavior. In: R.L. Day \& K.H. Hunt (Eds.), Proceeding of the Consumer Satisfaction/Dissatisfaction \& Complaining Behavior: New Dimensions of Consumer Satisfaction and Complaining Behavior, October 5-6. 190-195.

Day, R.L., \& Bodur, M. (1978). Consumer Response to Dissatisfaction with Services and Intangible Products. In H.H. Keith (Ed.), Advances in Consumer Research, 5th ed. (pp. 263-272). Association for Consumer Research.

Dick, A.A., Hausknecht, D.R., \& Wilkie, W.L. (1995). Consumer Durable Goods: A Review of Post-Purchase Issues. Journal of Consumer Satisfaction. Dissatisfaction and Complaining Behavior, 8, 111-123.

FitzPatrick, M., Friend, L., \& Costley, C. (2004). Dissatisfaction and Distrust. Journal of Consumer Satifaction, Dissatisfaction and Complaining Behavior, 17, 117-129.

Fornell, C., \& Wernerfelt, B. (1987). Defensive Marketing Strategy by Customer Complaint Management: A Theoretical Analysis. Journal of Marketing Research, 24(4), 337-346.

Fornell, C., \& Didow, N.M. (1980). Economic Constraints on Consumer Complaining Behavior. In J.C. Olson (Ed.), Advances in Consumer Research, 7th ed. (pp. 318-323). Ann Abor: Association for 
Consumer Research.

Fornell, C. (1976). Consumer Input for Marketing Decision: A Study of Corporate Departments for Consumer Affairs. New York: Praeger.

Gilly, M.C. (1979). Complaining consumers and the concept of expectations. In R.L. Day (Ed.), Refining Concepts and Measures of Consumer Satisfaction and Complaining Behavior. (pp. 35-43). Bloomington, IN: Indiana University.

Greyser, S.A. (1976). Introduction to Conference Proceeding, Conceptualization and Measurement of Consumer Satisfaction and Dissatisfaction. In: K.H. Hunt (Ed.), Proceedings of the Conference Conducted by the Marketing Science Institute with support from the National Science Foundation. Cambridge, Massachusetts: Marketing Science Institute, Massachusetts.

Johnston, R. (1998). The Effect of Intensity of Dissatisfaction on Complaining Behaviour. Journal of Consumer Satifaction, Dissatisfaction and Complaining Behavior, 11, 69-77.

Krishnan, S., \& Valerie, V.A. (1979). Dissatisfaction Attributions and Consumer Complaint Behavior. In W.L. Wilkie (Ed.), Advances in Consumer Research, 6th ed. (pp. 445-449). Ann Abor: Association for Consumer research.

LaBarbera, P.A., \& Mazursky, D. (1983). A Longitudinal Assesment of Consumer Satisfaction/Dissatisfaction: The Dynamic Aspects of the Cognitive Process. Journal of Marketing Research, 20, 393-404.

Landon, E.L.J. (1977). A Model of Consumer Complaint Behavior. In: Second Annual Conference on Consumer Satisfaction/Dissatisfaction and Complaining Behavior, Indian University, Bloomington, Indiana.

Lundstrom, W.J., White, S.D., \&
McAuley, A. (2004). Consumer Dissatisfaction: A Cross-Cultural Comparision. Journal of International Business and Economics, 2(1), 99-110.

Mills, M.K. (1981). Deviance and Dissatisfaction: An Exploratory Study. In K.B. Monroe (Ed.), Advances in Consumer Research, 8th ed. (pp. 682-686). Ann Abor: Association for Consumer research.

Oliver, R.L., \& de Sarbo, W.S. (1988). Response Determinants in Satisfaction Judgments. Journal of Consumer Research, 14(4), 495-507.

Oliver, R.L. (1987). An Investigation of the Interrelationship Between Consumer (Dis) Satisfaction and Complaint Reports. In M. Wallendorf \& P. Anderson (Eds.), Advances in Consumer Research, 14th ed. (pp. 218-222). Provo, UT: Association for Consumer Research.

Oliver, R.L. (1980). A Cognitive Model of the Antecedents and Consequences of Satisfaction Decisions. Journal of Marketing Research, 17(4), 460-469.

Pfaff, A.B. (1972). An Index of Consumer Satisfaction. In: Proceedings of the Third Annual Conference, Association for Consumer Research, November. 713-737.

Prakash, V. (1991). Intensity of Dissatisfaction and Consumer Complaint Behaviors. Journal of Consumer Satifaction, Dissatisfaction and Complaining Behavior, 4, 110-122.

Richins, M.L. (1983). Negative Word-ofMouth bu Dissatisfied Consumers: A Pilot Study. Journal of Marketing, 47, 68-78.

Singh, J., \& Pandya, S. (1991). Exploring the Effects of Consumers\&apos; Dissatisfaction Level on Complaint Behaviours. European Journal of Marketing, 25(9), 7-21.

Singh, J., \& Widing, R.E. (1991). What Occurs Once Consumers Complain? A 
Theoretical Model for Understanding Satisfaction/ Dissatisfaction Outcomes of Complaint Responses. European Journal of Marketing, 25(5), 30-46.

Singh, J. (1990). Identifying Consumer Dissatisfaction Response Styles: An Agenda for Future Research. European Journal of Marketing, 24(6), 55-72.

Sirgy, J.M. (1980). Towards a Psychological Model of Consumer Satisfaction/Dissatisfaction. In: R.L. Day \& K.L. Hunt (Eds.), Proceeding of the Consumer Satisfaction/Dissatisfaction \& Complaining Behavior, New Findings on Consumer Satisfaction and Complaining, November 6-8. 40-47.

Summers, J.O., \& Granbois, D.H. (1977). Predictive and Normative Expectations in Consumer Dissatisfaction and Complaining Behaviour. In W.D. Perreault (Ed.), Advances in Consumer Research, 4th ed. (pp. 155-158). Atlanta: Association for Consumer research.

Taylor, K.A., \& Burns, M.J. (1999). Changes in Pre-and Post-Purchase Evaluative Criteria: Exploring the Impact on Consumer (Dis) Satisfaction. Journal of Consumer Satifaction, Dissatisfaction and Complaining Behavior, 12, 90-99.

Tolman, E.C. (1932). Purposive behavior in animals and men. New York: AppletonCentury.

Warland, R. (1977). A Typology of Consumer Complaints. In R.L. Day (Ed.), Consumer Satisfaction, Dissatisfaction and Complaining Behaviour. (pp. 144-146). Bloomington, Indiana: Indian University.

Wee, C., \& Cheong, C. (1991). Determinants of Consumer Satisfaction/Dissatisfaction towards Dispute Settlements in Singhapore. European Journal of Marketing, 25(10), 6-16.

Westbrook, R.A. (1977). A Study of
Consumer Dissatisfaction Before Purchase. In W.D.J. Perreault (Ed.), Advances in Consumer Research, 4th ed. (pp. 142-148). Atlanta: Association for Consumer research.

Zeelenberg, M., \& Pieters, R. (2004). Beyond valence in customer dissatisfaction: A review and new findings on behavioral responses to regret and disappointment in failed services. Journal of Business Research, 57, 445-455. 